\title{
Environmental Issues and Corporate Social Responsibility: A literature and its Methods.
}

\author{
M. Ramaganesh, S. Bathrinath
}

\begin{abstract}
An enormous and developing assortment of literature to environmental issues and corporate social responsibility exists. Literatures on merging the environmental issues in the industry with corporate social responsibility are relatively limited. In order to merging these two, qualitative and quantitative data's are used to identify the environmental issues in various industries. Considering this developing exploration area, the objective and aim for this paper is to analyze research in international scientific journals that focus on environmental issues, corporate social responsibility, and green supply chain management. We recommend the following queries need to be addressed: (i) what are the common factors considered? (ii) What are the popular MCDM tools used to solve the problems? (iii) What are possible suggestions can be followed? We find that common factors are categorized under three main categories such as social, economic and environmental factors. Common factors are further segregated into sub factors. The most common MCDM tool used was “, DEMATEL ISM and AHP”. Further analysis was done and gaps in literature are identified. These gaps aid us to find improvements for corporate social responsibility and possible future directions.
\end{abstract}

Keywords: Environmental issues, corporate social responsibility, Green supply chain management, Interpretative Structural modeling (ISM), TOPSIS, DEMATEL, Analytic Network Process, Analytic Hierarchy Process.

\section{INTRODUCTION}

Companies have started realizing the importance of the environment and are making conscious efforts to implement various activities to preserve the environment in their business through designed reduction of wastes or recycle, rework, remanufacture etc., and through ethical acts. With regards to overseeing supply chains, it is imperative to think about whether all providers and organizations in the chain actualize CSR exercises and practices. Green supply chain management is being concerned for both development and eminent difficulties are observed through supply chain mining activities. The aim of this paper is to identify the possible ways to protect the environmental from the industrial activities. Previous literatures are collected and analysis was carried out to find the ways. Various industries like Mining, auto components, Textile etc. are considered to merge the identified environmental issues with corporate

Revised Manuscript Received on December 29, 2019.

* Correspondence Author

M.Ramaganesh, Department of Mechanical Engineering, Kalasalingam Academy of Research and Education, Krishnankoil, India, Email: ramaganesh87@gmail.com

S.Bathrinath*, Department of Mechanical Engineering, Kalasalingam Academy of Research and Education, Krishnankoil, India. Email: bathri@gmail.com social responsibility. In the other hand, further analysis was carried out for the combination of MCDM tools to solve the identified issues.

\section{LITERATURE REVIEW}

Literature section is segregated into different parts with respect to different areas.

\section{A. Corporate Social Responsibility in Supply Chain Management}

Baskaran et al. [2] highlighted the importance of supplier selection by considering CSR issues rather than usual selection criteria consideration of cost, delivery, quality, etc. He considered six CSR criteria's like child labour, unfair competition, discrimination, long working hours, pollution and abuse of human rights to measure small scale and medium scaled suppliers who produce products for textile and automotive industries. Seuring et al. [27] projected four important factors to highlight CSR usage over supply chains like (1) defining pressures and incentives for CSR applications across supply chains, (2) classifying and computing the effect of such applications, (3) specifying and handling various problems at the supplier-consumer interface, and (4) handling, applying, and integrating CSR applications into working procedures by considering the entire product's life cycle. Mani et al. [21] investigated social issues pertinent to suppliers to recognize measures and measurements that were in consonance with social sustainability in emerging economics. A review was accompanied in Indian manufacturing industries and a co-variance based structural equation modeling was used to analyze the hypothesized model. Eighteen supplier social sustainability estimates basic five social measurements: labor rights, safety and health, societal responsibility, diversity, and product responsibility were validated. Cruz et al., [4] developed an outline for the analysis of optimal levels of CSR activity in a multi-period supply chain network of manufacturers, retailers and customers. They analyzed the impact of the cost of CSR based on investing in such activities and found that as the cost increased a firm would have less incentive to invest in such activities. Li et al. [18] identified influential indicators in adopting sustainable supply chain management in the auto components manufacturing sector using the DEMATEL approach. They identified that Carbon management indicator played a major role in 15 Sustainable Development indicators arrived at from various literature and experts opinions. Kulkarni et al. [16] did a relative study of corporate social responsibility performs across Africa and India in the automobile industry and indicated that CSR activities were parallel 
at the economic and philanthropic levels. Rajak et al., [26] evaluated social sustainability performance in an Indian auto component manufacturing organization using fuzzy logic.

They validated the calculated social sustainability index using the conventional crisp approach which helped identify weaker areas and resulted in proposals being developed for social sustainability improvement. Ghadimi et al. [6] established a weighted fuzzy assessment method for product sustainability valuation showing that a simple product could contribute to sustainability improvement and ensure sustainable manufacturing through an automotive industry case study. Mathiyazhagan et al. [22] used the ISM approach to barrier analysis when applying green supply chain management through a case study in auto components manufacturing industry.

\section{B. Green supply chain management}

Govindan et al. [9] reviewed different literatures about various multi criteria decision making approaches for green supplier evaluation and selection. Toke et al. [28] applied the same process (AHP) to find the comparative prominence and select an appropriate approach to Green Supply Chain Management practices in the Indian manufacturing area. Uygun et al. [29] proposed a model based on integrated Fuzzy MCDM methods to assess GSCM performance in organizations regarding green design, green purchasing, green transformation, green logistics and reverse logistics. Govindan et al. [7] reviewed literature related to Multi criteria decision making methods for green supplier evaluation and selection and found that Fuzzy based single model approach was resorted to commonly and that the most common factor considered for green supply selection was 'Environmental Management Systems'. Diabat et al. [5] used Interpretive Structural modeling (ISM) for identifying the factors affecting green supply chain management. The model was developed and validated through a case study in an Indian manufacturing firm. Govindan et al. [8] identified the barriers to implementing a green supply chain based on procurement effectiveness in Indian Industries using Analytic hierarchy process and confirming that the green supply chain management is capable of clearing the barriers and can manage a green enabled environment during mining. But the identification of the barriers will be a crucial one. Sahay et al. [3] suggested the supply chain management strategy in Indian industry should be done along with business strategy. Jenkins et.al, [15] performed research on recent trends in the area of mining industries and suggested the impacts and detailed review was conducted in world's 10 largest mining industries for the development of social and environmental activities using a case study. Simonov et.al. [17] analyzed the green supply chain practices are followed in mining industries to reduce the rate of environmental issues. The environmental issues considered are soil erosion, earthquake and chemical explosive. Those issues are evaluated and rated by using fuzzy TOPSIS methodology. They suggested that other weighing techniques such as Analytical hierarchy process (AHP) can be used for making comparisons. Pfohl H C et al. [25] developed a interpretive structural modeling for supply chain risks. They analyzed the relationship among the potential supply chain risks and their dependency among each other is observed and derived. It is solved by considering both the driving and the dependent power by analyzing the risk and classifying them according to their power. ISM is an effective tool in structuring the supply chain risk in an easy way. Luthra et al. [19] used ISM to analyze the obstacles in the implement of green supply chain management in automobile industry. Razmi et.al. [20] developed a Fuzzy ANP model to evaluate the potential suppliers and select the best supplier based on by considering vendor important factors. They also used fuzzy set theory to cover the indeterminacy of decisions made. The supplier criteria considered are supplier's qualitative capability, supplier's delivery capability, supplier financial status and supplier performance antecedents etc. These criteria are compared by pair wise comparison and then rated as per scoring scale. As a result, global value denotes the important criteria for development. From the comparison matrix, nonlinear programming model was developed and validated by taking numerical samples.

\section{Mining industry}

Muduli et al. [23] examined the obstacles to green supply chain management in Indian mining industries using graph theory. Mining industry has to adopt necessary steps like environmental management system, cleaner production, etc. to protect the environmental problems. Green supply chain management system will help to reduce the energy and usage of materials and improve the efficiency level in doing mining. Four major barriers (Information gap, lack of social concerns, poor legislation and capacity constraints) were identified and validated by statistical tests. Muduli et al. [30] explained the role of social issues in green supply chain management execution in Indian mining industries. GSCM will vary according to the human behavioral changes. In the mine supply chains, it is needed to enable green practice in order to manage the environmental issues. Barve et al. [1] performed analysis on green supply chain management practices in Indian mining industries and created a model for the same. They analyzed the barriers like lack of poor legislation environmental awareness, and inadequate pressure from society. Hilson et al. [14] examined the mining industry for sustainable development in corporate perspective view. They suggested that sustainability of the industry will be more effective by handling all the degrading factors and they explained to make industry as more sustainable one, industry has to ensure the environmental clearing and taking, social remedies. Jenkins et al. [11] discussed the corporate social responsibility in the mining industry. They endorsed enclosing the social and environmental information in the company's procedure while doing mining can justify their product with their description. This is considered as an essential one in the developing mining industry to value their project as higher one. Jenkins $\mathrm{H}$ et al. [12] analyzed the conflicts and constructs in corporate social responsibility for mining industry. They briefed about the corporate responsibility about the environmental, sustainability factors and also these kind of taking over led to the change in the strategy of mining in how to deal it and bring out new outcomes in facing such problems. It also needs

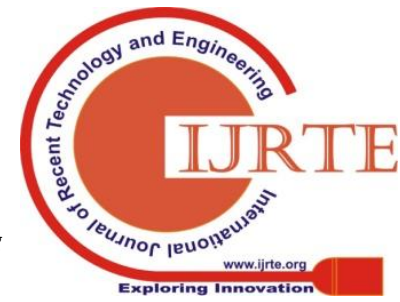


to understand better about the complex nature of handling the social and environmental problems. Silva et.al. [31] made the comparison of the environmental issues among different nations rather than single coal mining industry. The coal fires in the mining industry are studied using advanced electron beam and x-ray diffraction technique.

The mineral constitution in the coal fire is calcite, gypsum, quartz and also small quantity of Sulphur, pyrite, magnate and chlorite, dolomite also detected. The soil sample from coal drainage is tested for particle size using Nikon SMZ645 dividing optical microscope. They found the results as the emission of $\mathrm{CO}_{2}, \mathrm{CO}, \mathrm{CH}_{4}, \mathrm{C}_{4} \mathrm{H}_{10}$, and $\mathrm{C}_{6} \mathrm{H}_{6}$ varies for different month which affect the environment as well as human health in the mining industry area.

\section{Environmental Issues in supply chain management}

Jia et al. [13] analyzed criteria to choose an environment shipping carrier and find the most significant factor from the point view of environmental practices using DEMATAL through a case study from an Indian Ocean shipper. O'Regan et al. [24] used system dynamics interaction model between environmental and economic factors in the mining industry. This brings out choice for improved comprehension of the system structure. It upgrades the sustainability of the system structure. Wang Q et al. [32] explained about the sources and remediation for mercury contamination in aquatic systems. Contamination of the water bodies with mercury leads to drastic changes in the water area and the organisms living in and around. Capping and dredging are considered as the two important remedial measures for overcoming the mercury pollution. Song et al. [33] explained the analysis of photovoltaic and wind power systems used in the mining industry. Photovoltaic and wind power systems employed in the mines to solve the energy supply problems and to have benefit from the exhausted mines. Zhengfu et al. [35] explained about the environmental problems that occur during coal mining and the reusability of waste received. It is common in some countries in using the waste products for their raw materials. After completion of mining process, the land lying vacant has been used for agricultural and some other activities. Woo [10] discussed mining, pollution and site remediation which includes environmental issues like pollution occurs during mining including top-soils, sediments, aquifer and groundwater, and streams. Proper maintenance of mining site and doing activity should be done. Bian et.al. [34] proposed a two-way method to recreate the farmer's house in china and also introduced a methodology to solve environmental problems. Coal production in china is increased accordingly by the reduction of number of coal mines to around $50 \%$. Some of the reclamation activities followed by mining industry to reduce environmental effect is recreation of rural commodities, native residential improvement etc. discussed the environmental issues related to coal mine accidents, land subsidence, emission of gases etc. The major emission of the industry is methane. At the same time methane is used for electricity generation and industrial purpose. To reduce the environmental issues the waste, need to be reused as fuel for power generation and making of bricks etc. the land which involved for coal mining are need to be involve for land recreation, agriculture purpose etc. Tiwary [36] suggested a two-tier management system to minimize the impact of mine waste water to the surroundings. Initial level management suggests that while considering the land usage, ground water stream for the determination of the dumping destinations to stay away from effect on ground and surface water quality. Secondary level management recommends that the protectionary measures taken to limit the soil erosion, acid mine drainage, etc. Sloss [37] explained briefly about the corporate social responsibility on mining industry. The factors which are all get affected are land, water etc. The factors that cause the degradation are greenhouse gas, truck and mine site machinery, dust and transport are explained along with many case studies. Various technique to control the waste, the company standards, and major coal exporting countries are described.

\section{CONCLUSION}

Various literatures related to corporate social responsibility and Environmental issues in different industries like mining, textile, auto components manufacturing industry are discussed. They categorized into three main categories like social, economic and environmental factors. Under each main factor, sub factors are identified and arranged. Multi criteria decision making (MCDM) tools are used to relate the sub factors and main factors. From the analysis major influence factors is identified for corporate social responsibility activities. From the results, most influencing factor will take as first priority and recommended solutions will be suggested to eliminate the same. In the future work, combination of various factors and MCDM tool will be considered and the solution will be generated.

\section{REFERENCES}

1. A.Barve and K.Muduli,"Modelling the challenges of green supply chain management practices in Indian mining industries," Journal of Manufacturing Technology Management, 2013, vol:24(8), pp. 1102-1122.

2. V.Baskaran, S.Nachiappan and S.Rahman, "Supplier assessment based on corporate social responsibility criteria in Indian automotive and textile industry sectors," International Journal of Sustainable Engineering, 2011, vol:4(4), pp.359-369.

3. B.S.Sahay, and R.Mohan, "Supply chain management practices in Indian industry," International Journal of Physical Distribution \& Logistics Management, 2003, vol:33(7), pp.582-606.

4. J.M.Cruz and T.Wakolbinger,'Multiperiod effects of corporate social responsibility on supply chain networks, transaction costs, emissions, and risk," International journal of production economics, 2008, vol:116(1), pp.61-74.

5. A.Diabat and K.Govindan,"An analysis of the drivers affecting the implementation of green supply chain management. Resources, Conservation and Recycling," 2011, vol:55(6), pp.659-667.

6. P.Ghadimi, A.H.Azadnia N.M.Yusof and M.Z.M.Saman,"A weighted fuzzy approach for product sustainability assessment: a case study in automotive industry," Journal of Cleaner Production, 2012, vol:33, pp.10-21.

7. K.Govindan, D.Kannan, and K.M.Shankar, "Evaluating the drivers of corporate social responsibility in the mining industry with multi-criteria approach: A multi-stakeholder perspective," Journal of cleaner production, 2014, vol:84, pp.214-232.

8. K.Govindan, M.Kaliyan D.Kannan, and A.N.Haq,"Barriers analysis for green supply chain management implementation in Indian industries using analytic hierarchy process," International Journal of Production Economics, vol:147, pp.555-568.

9. K.Govindan, S.Rajendran, J.Sarkis and P.Murugesan, "Multi criteria decision making 
approaches for green supplier evaluation and selection: a literature review.," Journal of Cleaner Production, 2011, vol:98, pp.66-83.

10. N.C.Woo, and M.J.Choi, "Arsenic and metal contamination of water resources from mining wastes in Korea," Environmental Geology, 2001, vol:40(3), pp.305-311.

11. H.Jenkins, and N.Yakovleva, "Corporate social responsibility in the mining industry: Exploring trends in social and environmental disclosure," Journal of cleaner production, 2006, vol:14(3-4) pp.271-284.

12. H.Jenkins, "Corporate social responsibility and the mining industry: conflicts and constructs. Corporate Social Responsibility and Environmental Management," 2004, vol:11(1), pp.23-34.

13. P.Jia, K.Govindan, and D.Kannan, "Identification and evaluation of influential criteria for the selection of an environmental shipping carrier using DEMATEL: a case from India," International Journal of Shipping and Transport Logistics, 2004, vol:7(6), pp.719-741.

14. G.Hilson, and B.Murck, "Sustainable development in the mining industry: clarifying the corporate perspective," Resources policy, 2000, vol:26(4), pp.227-238.

15. H.Jenkins, and L.Obara, "Corporate Social Responsibility (CSR) in the mining industry-the risk of community dependency,"Queen's University Belfast, 2006.

16. S. Kulkarni and P.Rao, "Comparative analysis of corporate social responsibility practices across Africa and India-An Automobile Industry Perspective," Procedia-Social and Behavioral Sciences, 2014, vol:157, pp.244-253.

17. S.Kusi-Sarpong, C.Bai, J.Sarkis and X.Wang, "Green supply chain practices evaluation in the mining industry using a joint rough set and fuzzy TOPSIS methodology," Resources Policy, 2014, vol:46, pp.86-100.

18. Li, Y., \& Mathiyazhagan, K. (2018). Application of DEMATEL approach to identify the influential indicators towards sustainable supply chain adoption in the auto components manufacturing sector. Journal of Cleaner Production, 172, 2931-2941.

19. 19.S.Luthra K.Govindan, and S.K.Mangla, "Structural model for sustainable consumption and production adoption-A grey-DEMATEL based approach," Resources, Conservation and Recycling, 2017, vol:125 ,pp.198-207.

20. 20 J.Razmi, H.Rafiei, and M.Hashemi, ”Designing a decision support system to evaluate and select suppliers using fuzzy analytic network process," Computers \& Industrial Engineering, 2009, vol:57(4), pp.1282-1290.

21. 21. V.Mani, A.Gunasekaran, and C.Delgado, "Enhancing supply chain performance through supplier social sustainability: An emerging economy perspective," International Journal of Production Economics, 2018, vol:195, pp.259-272.

22. 22. K.Mathiyazhagan, K.Govindan, A.NoorulHaq, and Y.Geng, "An ISM approach for the barrier analysis in implementing green supply chain management," Journal of Cleaner Production, 2013, vol:47, pp.283-297.

23. 23. K.Muduli, and A.Barve, "Empirical investigation of the barriers of Green Supply Chain Management (GSCM) implementation in Indian mining industries," In 3rd International Conference on Business, Economics, Management and Behavioral Sciences (ICBEMBS'2013) April 29-30, 2013 Singapore.

24. 24. B.O'Regan, and R.Moles, "Using system dynamics to model the interaction between environmental and economic factors in the mining industry," Journal of cleaner production, 2013, vol:14(8), pp.689-707.

25. 25. H.C.Pfohl, P.Gallus, and D.Thomas, "Interpretive structural modeling of supply chain risks," International Journal of physical distribution \& logistics management, 2011, vol:41(9), pp.839-859.

26. 26.S.Rajak, and S.Vinodh, "Application of fuzzy logic for social sustainability performance evaluation: a case study of an Indian automotive component manufacturing organization," Journal of Cleane Production, 2015, vol:108, pp.1184-1192.
27. 27. S.Seuring and M.Müller, "From a literature review to a conceptual framework for sustainable supply chain management," Journal of cleaner production, 2008, vol:16(15), pp.1699-1710.

28. 28. L.K.Toke, "An empirical study of green supply chain management in Indian perspective," International Journal of Applied Science and Engineering Research, 2012.

29. 29.O.Uygun, and A.Dede, "Performance evaluation of green supply chain management using integrated fuzzy multi-criteria decision making techniques," Computers \& Industrial Engineering, 2016, vol:102, pp. $502-511$.

30. 30. K.Muduli, and A.Barve, "Role of green issues of mining supply chain on sustainable development," International Journal of Innovation, Management and Technology, 2011, vol:2(6), pp.484.

31. 31. L.F.Silva, M.L.Oliveira, E.R.Neace, O'Keefe, J.M.Henke, and J.C.Hower, "Nanominerals and ultrafine particles in sublimates from the Ruth Mullins coal fire, Perry County, Eastern Kentucky, USA,' International Journal of Coal Geology, 2011, vol:85(2), pp.237-245.

32. 32. Q.Wang, D.Kim, D.D.Dionysiou, G.A.Sorial, and D.Timberlake "Sources and remediation for mercury contamination in aquatic systems a literature review," Environmental pollution, 2004, vol:131(2), pp.323-336.

33. 33. J.Song, and Y.Choi, "Analysis of the potential for use of floating photovoltaic systems on mine pit lakes: Case study at the ssangyong open-pit limestone mine in Korea," Energies, 2016, vol: 9(2), pp.102.

34. 34. Z.Bian, J.Dong, S.Lei, H.Leng, S.Mu and H.Wang, "The impact of disposal and treatment of coal mining wastes on environment and farmland," Environmental Geology, 2009, Vol: 58(3), pp.625-634

35. 35. B.I.A.N.Zhengfu, H.I.Inyang, J.L.Daniels, O.T.T.O.Frank, and S.Struthers, "Environmental issues from coal mining and their solutions. Mining Science and Technology (China)," 2010, vol:20(2), pp. 215-223

36. 36. R.K.Tiwary, "Environmental impact of coal mining on water regime and its management. Water, Air, and Soil Pollution," 132(1-2), 2001, pp.185-199.

37. 37. LL.Sloss "Environmental and other effects of coal mining and transport. IEA clean coal centre, 2017," 978-92-9029-604-1.

\section{AUTHORS PROFILE}

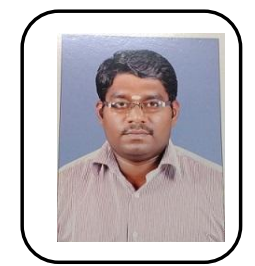

M.Ramaganesh obtained his Bachelor of Engineering in Mechanical Engineering from Arulmigu Kalasalingam College of Engineering, India in 2008. He finished his Master of Engineering in Industrial Engineering from Thiagarajar College of Engineering, India in 2015. He is currently taking up Doctor of Engineering with specialization in Industrial Engineering from Kalasalingam Academy of Research and Education, India. $\mathrm{He}$ is the member of Indian Society for Technical Education. His research interest includes Sustainability, Supply Chain Management, Environmental Management System and Corporate Social Responsibility.

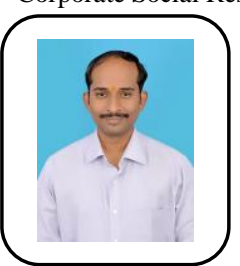

Dr.S.Bathrinath is an Associate Professor in the Department of Mechanical Engineering, Kalasalingam Academy of Research and Education, Krishnankoil, Tamilnadu, India. His current area of research includes multi-criteria decision making, scheduling \& optimization, soft computing and Artificial intelligence. He has published a number of papers in journal of national/international repute and presented a number of papers in various conferences/symposia in India and abroad. He is presently guiding a number of master/doctoral research scholars. Dr.S.Bathrinath is the corresponding author and can be contacted at: bathri@gmail.com

\section{ANNEXURE}

Table-I: Literature Survey of CSR and Environmental issues

\begin{tabular}{|c|c|c|c|c|c|}
\hline S.No & Authors \& Year & $\begin{array}{l}\text { Main Factors } \\
\text { Considered }\end{array}$ & Sub Factors Considered & Application & Methodology Used \\
\hline 1. & $\begin{array}{l}\text { Baskaran et.al } \\
\quad(2011)\end{array}$ & Discrimination & $\begin{array}{c}\text { Policies and Procedures against } \\
\text { Discrimination }\end{array}$ & $\begin{array}{l}\text { Indian automotive } \\
\text { and textile industry } \\
\text { sectors }\end{array}$ & $\begin{array}{c}\text { Questionnaire \& } \\
\text { Hypothesis }\end{array}$ \\
\hline
\end{tabular}




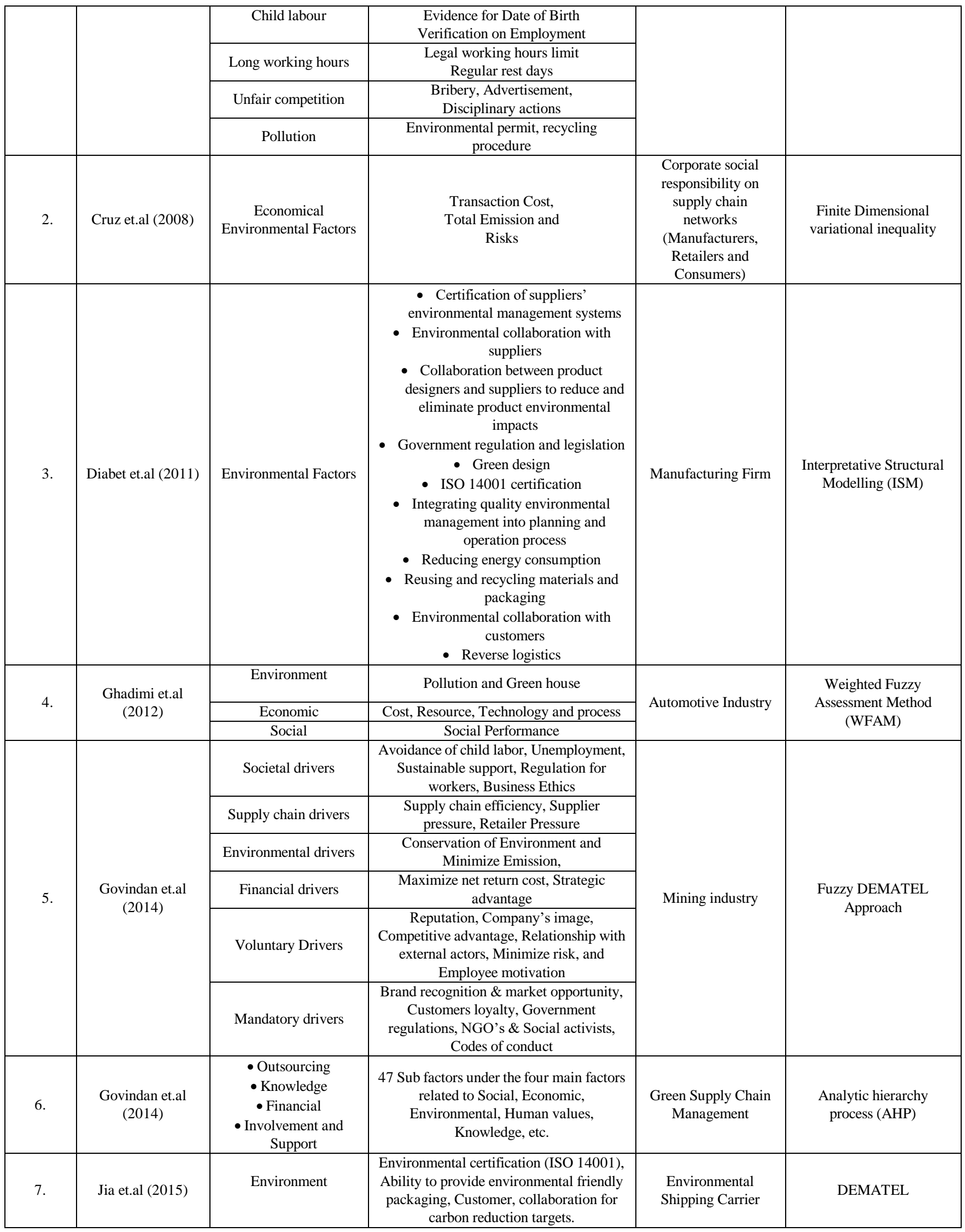


Environmental Issues and Corporate Social Responsibility: A review of the literature and its methods.

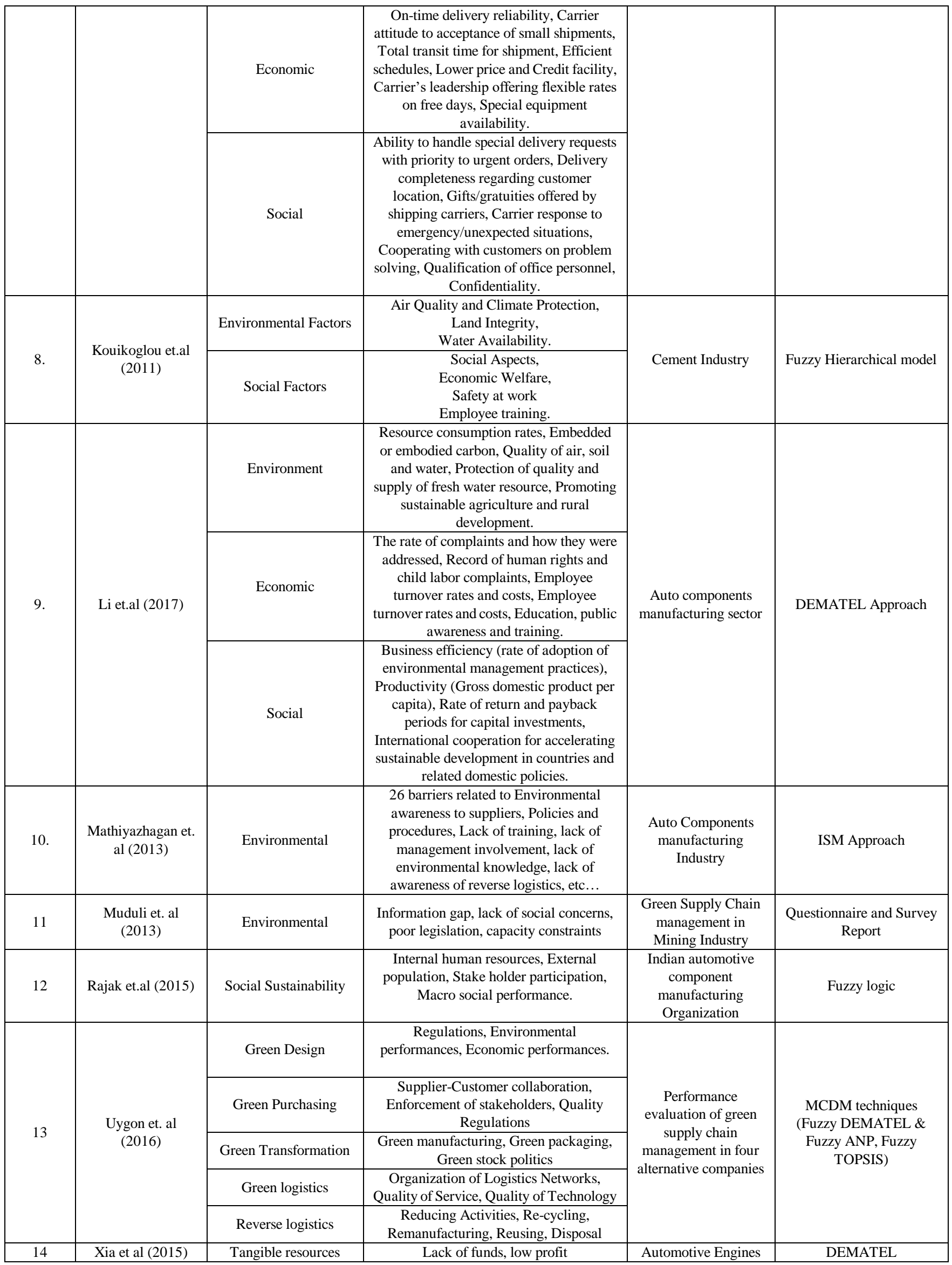

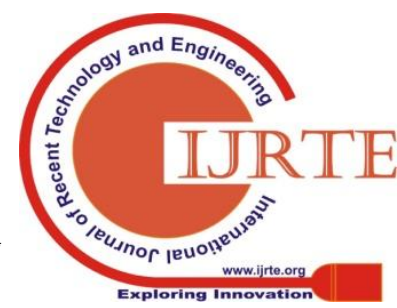


International Journal of Recent Technology and Engineering (IJRTE) ISSN: 2277-3878, Volume-8 Issue-4S4, December 2019

\begin{tabular}{|c|c|c|c|c|c|}
\hline & & Intangible resources & $\begin{array}{l}\text { Lack of skilled workers, cooperation and } \\
\text { information management system, } \\
\text { Incomplete recycling system }\end{array}$ & manufacturing firm & \\
\hline & & Capabilities (skills) & $\begin{array}{l}\text { Lack of R\&D skills, lack of technology, } \\
\text { lack of scientific plans }\end{array}$ & & \\
\hline 15 & $\begin{array}{l}\text { Aryafar et al } \\
\qquad(2013)\end{array}$ & $\begin{array}{l}\text { Issues in groundwater } \\
\text { pollutions }\end{array}$ & $\begin{array}{c}\text { Surface media, Net recharge, Vadose zone } \\
\text { material, Extension of vegetation, Depth } \\
\text { to the water table, Aquifer media, } \\
\text { Hydraulic conductivity }\end{array}$ & Mining Industry & Fuzzy AHP method \\
\hline \multirow[b]{2}{*}{16} & \multirow[b]{2}{*}{ Dyna (2010) } & Sustainability & $\begin{array}{c}\text { Rational exploitation of natural } \\
\text { Resources, Clean extraction technologies, } \\
\text { Mine closure and recovery programs, } \\
\text { Emergency management, Quality of } \\
\text { production. }\end{array}$ & \multirow[b]{2}{*}{$\begin{array}{l}\text { CSR in Mining } \\
\text { Industry }\end{array}$} & \multirow[b]{2}{*}{ CSR Performance Chart } \\
\hline & & Ethics & $\begin{array}{l}\text { Promotion of local community } \\
\text { economy and social work, Fair funds } \\
\text { administration, Job security and dignity }\end{array}$ & & \\
\hline 17 & Kitula et al (2006) & $\begin{array}{l}\text { Social \& } \\
\text { Environmental factors }\end{array}$ & $\begin{array}{l}\text { Human health, Pollution, Deforestation, } \\
\text { Effects of mercury chemical, collapsing of } \\
\text { buildings. }\end{array}$ & Mining Industry & Field Survey \\
\hline \multirow{6}{*}{18} & \multirow{6}{*}{$\begin{array}{l}\text { Kusi-Sarpong et al } \\
\qquad(2015)\end{array}$} & $\begin{array}{l}\text { Green Information } \\
\text { Technology and } \\
\text { Systems }\end{array}$ & $\begin{array}{l}\text { Efficient Energy usage, Waste reduction, } \\
\text { Eco-labelling of IT products }\end{array}$ & \multirow{6}{*}{ Mining Industry } & \multirow{6}{*}{ TOPSIS } \\
\hline & & $\begin{array}{l}\text { Strategic Suppliers } \\
\text { Partnership }\end{array}$ & $\begin{array}{c}\text { jointly develop environmental } \\
\text { management solutions, Collaborate with } \\
\text { suppliers, }\end{array}$ & & \\
\hline & & $\begin{array}{l}\text { Operations and } \\
\text { Logistics Integration }\end{array}$ & $\begin{array}{l}\text { Lean and green operations, Process } \\
\text { redesign, employee health and safety } \\
\text { concerns, Internal process integration and } \\
\text { production automation }\end{array}$ & & \\
\hline & & $\begin{array}{l}\text { Internal Environmental } \\
\text { Management }\end{array}$ & $\begin{array}{l}\text { Total quality environment management, } \\
\text { Pollution prevention plans, Employee } \\
\text { incentive programs for environmental } \\
\text { suggestions }\end{array}$ & & \\
\hline & & $\begin{array}{l}\text { Eco-Innovation } \\
\text { practices }\end{array}$ & $\begin{array}{l}\text { Use of fewer inputs to minimize the } \\
\text { environmental risks and impact, Internal } \\
\text { recycling of inputs, materials and wastes, } \\
\text { Switching from "dirty" to cleaner } \\
\text { technologies }\end{array}$ & & \\
\hline & & End-of-Life practices & $\begin{array}{l}\text { Resale, Recondition and refurbishing of } \\
\text { used parts, Mining of tailings }\end{array}$ & & \\
\hline 19 & $\begin{array}{l}\text { Mamurekli et al } \\
\text { (2010) }\end{array}$ & $\begin{array}{l}\text { Environmental } \\
\text { Problems }\end{array}$ & $\begin{array}{c}\text { Dust, noise, vibration, Destruction of } \\
\text { ground water, Impact on land and water, } \\
\text { Health hazards, Air Pollution, Acid rain, } \\
\text { Solid waste pollution }\end{array}$ & Mining Industry & $\begin{array}{l}\text { Questionnaire, Survey } \\
\text { report }\end{array}$ \\
\hline
\end{tabular}

